\title{
UPAYA MENINGKATKAN HASIL BELAJAR IPA MATERI PEWARISAN SIFAT MELALUI MODEL COOPERATIVE LEARNING TIPE STUDENT TEAM ACHIEVEMENT DIVISION (STAD) SISWA KELAS 9H DI SMP NEGERI PAKUSARI JEMBER
}

\author{
${ }^{1)}$ Endah Noer Aini \\ ${ }^{1)}$ SMP Negeri Pakusari Jember \\ Email: Cheppysukma@gmail.com
}

\begin{abstract}
Natural Science learning that took place $9 H$ class at Pakusari State Junior High School in 2018/2019 still did not get the results desired, this is because the learning model used was not optimal to achieve student learning outcomes in accordance with the Curriculum Target. The formulation of the problem in this study are (1) How the Student Team Achievement Division (STAD) learning model can improve the learning outcomes of inheritance science material in $9 H$ grade students of Pakusari State Junior High School in Jember 2018/2019 academic year. The data obtained in this study include the average evaluation learning outcomes for the first cycle that is 83.94, for the second cycle that is 85, the evaluation results can be seen that there is a significant increase in the average student learning outcomes from Cycle I to Cycle II, which is 1.05. This shows that in the first cycle students' learning completeness has not been achieved that is equal to $89.47 \%$, while in the second cycle increased to $92.10 \%$ which suadah fulfill the minimum completeness of 75 and the average grade set is 85, the second cycle shows an increase of 1.05. Thus in the second cycle has reached the target, that learning the STAD Coopetive Learning type can improve the results of mathematics learning achievement.
\end{abstract}

Keywords: Cooperative Learning, STAD, IPA results

\section{PENDAHULUAN}

Hasil Ujian Nasional IPA tahun

2019, SMP Negeri Pakusari memperoleh nilai rata-rata 40,8 jauh berada dari rata-rata kabupaten $(49,05)$, rata-rata propinsi $(55,01)$ dan rata-rata Nasional $(49,82)$. Perolehan hasil seperti ini, menjadi tanggung jawab bersama. Kesulitan siswa dalam menyelesaikan soal-soal IPA, tidak lepas dari proses pembelajaran yang berlangsung di kelas.
Arifin (2017) menyatakan dalam penelitian yang berjudul "Penerapan Model STAD dapat meningkatkan Hasil Belajar pada materi penjumlahan, selama dua siklus diperoleh prosentase aktivitas peserta didik dalam model pembelajaran kooperatif tipe STAD meningkat menjadi $86,7 \%$ pada siklus II dan dikategorikan sangat aktif. Hasil belajar peserta didik dalam pembelajaran kooperatif tipe STAD perolehan nilai rata-rata peserta didik 
pada siklus II nilai rata-rata peserta didik meningkat menjadi 80,17 dengan prosentase ketuntasan $93,10 \%$.

Menurut Nurhadi (2010), pengertian belajar adalah suatu proses usaha yang dilakukan seseorang untuk memperoleh suatu perubahan tingkah laku yang baru secara keseluruhan, sebagai hasil pengalamannya sendiri dalam berinteraksi dengan lingkungannya. Hasil belajar adalah suatu akibat dari proses belajar dengan menggunakan alat pengukuran yaitu berupa tes yang disusun secara terencana, baik tes tertulis, tes lisan maupun tes perbuatan. S. Nasution berpendapat bahwa hasil belajar adalah suatu perubahan pada individu yang belajar, dimana perubahan tersebut tidak hanya berkaitan dengan pengetahuan tetapi juga berbentuk kecakapan, kebiasaan, pengertian, pengharusan dan penguasaan diri pribadi individu yang belajar (Ngalim, Purwanto, 2006). Dari beberapa pengertian di atas dapat dikatakan bahwa hasil belajar adalah hasil yang diperoleh peserta didik setelah mengikuti suatu materi tertentu dari mata pelajaran yang berupa data kuantitatif maupun kualitatif. Untuk mengetahui suatu hasil belajar perlu dilakukan penilaian terhadap peserta didik.

Pendidikan IPA di SMP khususnya diharapkan dapat menjadi wahana bagi peserta didik untuk mempelajari diri sendiri dan alam sekitar, serta prospek pengembangan lebih lanjut dalam menerapkannya di dalam kehidupan sehari-hari. Proses pembelajaran- nya menekankan pada pemberian pengalaman langsung untuk mengembangkan kompetensi agar menjelajahi dan memahami alam sekitar secara ilmiah. Pendidikan IPA diarahkan untuk inkuiri dan berbuat sehingga dapat membantu peserta didik untuk memperoleh pemahaman yang lebih mendalam tentang alam sekitar. Pembelajaran IPA dilaksanakan melalui inkuiri ilmiah (scientific inquiry) untuk menumbuhkan kemampuan berpikir, bekerja dan bersikap ilmiah serta mengkomunikasikannya sebagai aspek penting kecakapan hidup. Oleh karena itu pembelajaran IPA di SMP menekankan pada pemberian pengalaman belajar secara langsung melalui penggunaan dan pengembangan keterampilan proses dan sikap ilmiah.

Pembelajaran kooperatif adalah salah satu model pembelajaran yang menempatkan siswa sebagai subjek pembelajaran (student oriented), dengan suasana kelas yang demokratis, saling membelajarkan, memberi kesempatan peluang lebih besar dalam memberdayakan potensi siswa secara maksimal. Untuk memilih model yang tepat maka perlu diperhatikan relevansi pencapaian tujuan pembelajaran, dan juga bahwa dalam proses pembelajaran siswa dalam posisi proses mental yang aktif, dan guru berfungsi mengkondisikan terjadinya pembelajaran, dalam penerapannya model pembelajaran yang digunakan harus sesuai dengan kebutuhan siswa, untuk model yang tepat maka diperlukan relevansi dengan pencapaian tujuan pembelajaran.

Tipe STAD (Student Team Achievemen Division) merupakan 
salah satu tipe pembelajaran kooperatif yang menekankan pada adanya aktivitas dan interaksi untuk saling memotivasi dan membantu dalam menguasai materi pelajaran guna mencapai hasil belajar yang maksimal (Slavin dalam Isjoni, 2010:51). STAD merupakan salah satu model pembelajaran kooperatif yang paling sederhana, dan merupakan model yang paling baik untuk permulaan bagi para guru menggunakan pendekatan kooperatif Slavin (2009:23). Pembelajaran Kooperatif tipe STAD yang digunakan memberikan kesempatan kepada siswa untuk berkomunikasi sosial dengan temannya untuk mencapai tujuan pembelajaran, dalam pembelajaran ini kegiatan aktif dengan pengetahuan yang di bangun sendiri oleh siswa dan mereka bertanggung jawab atas hasil pembelajaran, di mana hasil yang diharapkan tidak hanya pengetahuan kognitif siswa tetapi juga aspek afektif dan psikomotorik siswa.

Pembelajaran kooperatif tipe STAD terdiri dari lima komponen utama (Isjoni, 2010) yaitu :

1. Penyajian kelas

Guru menyampaikan materi pembelajaran sesuai dengan penyajian kelas. Penyajian kelas tersebut mencakup pembukaan, pengembangan dan latihan terbimbing.

2. Kegiatan kelompok

Siswa mendiskusikan lembar kerja yang diberikan dan diharapkan saling membantu sesama anggota kelompok untuk memahami bahan pelajaran dan menyelesaikan permasalahan yang diberikan.

3. Kuis (Quizzes)

Kuis adalah tes yang dikerjakan secara mandiri dengan tujuan untuk mengetahui keberhasilan siswa setelah belajar kelompok. Hasil tes digunakan sebagai hasil perkembangan individu dan disumbangkan sebagai nilai perkembangan dan keberhasilan kelompok.

4. Skor kemajuan (perkembangan) individu. Skor

kemajuan individu ini tidak berdasarkan pada skor mutlak siswa, tetapi berdasarkan pada seberapa jauh skor kuis terkini melampui rata-rata skor siswa yang lalu.

5. Penghargaan kelompok

Penghargaan kelompok adalah pemberian predikat kepada masingmasing kelompok. Predikat ini diperoleh dengan melihat skor kemajuan kelompok. Skor kemajuan kelompok diperoleh dengan mengumpulkan skor kemajuan masing-masing kelompok sehingga diperoleh skor rata-rata kelompok.

Dari teori dan penjelasan, dapat disimpulkan bahwa model pembelajaran kooperatif tipe STAD adalah kegiatan pembelajaraan dengan melakukan berbagai aktivitas kelompok yang menciptakan peserta didik untuk menerima pendapat orang lain, saling bekerjasama, bertanggung jawab dalam kelompoknya dan mampu memecahkan masalah baik yang dirancang maupun masalah yang ada di sekitar. 


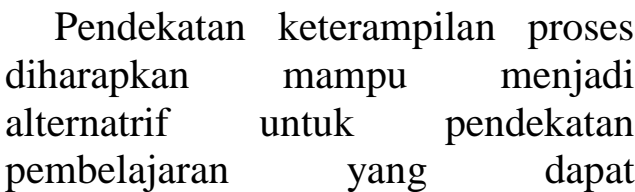
meningkatkan ketercapaian indikator pembelajaran. Keterampilan yang diperoleh melalui pendekatan keterampilan proses dapat dinilai melalui beberapa aspek, misalnya aspek fisik,aspek psikis, dan aspek sosial. Hal ini sejalan dengan pernyataan Lita (2004:33) yaitu keterampilan proses maupun keaktifan siswa dapat dilihat dari tiga segi , yaitu :

(1) Segi fisik, yang ditunjukan dalam bentuk gerak, perbuatan, katakata yang diamati dan terkait dengan konteks kegiatan belajar;

(2) segi psikis (mental), yang ditunjukan dalam olah pikir dan sikap yang mendukung kegiatan belajar; dan

(3) segi sosial, budaya, dan alam yang ditunjukan dengan pendayagunaan lingkungan dalam proses pembelajaran.

Menurut Gagne (dalam Dahar, 1995) keterampilan proses sains adalah keterampilan intelektual yang digunakan semua saintis untuk memahami fenomena alam. Keterampilan proses sains merupakan keterampilan yang melibatkan keterampilan-keterampilan kognitif atau intelektual, manual dan sosial. Keterampilan kognitif atau intelektual terlibat karena dengan melakukan keterampilan proses sains siswa akan menggunakan pikirannya. Keterampilan manual melibatkan dalam keterampilan proses sains karena mereka melibatkan penggunaan alat dan bahan, pengukuran, penyusunan atau perakitan alat. Sedangkan keterampilan sosial menggambarkan interaksi siswa dengan sesamanya dalam pembelajaran, misalnya mendiskusikan hasil pengamatan.

Menurut Usman (1993:78) pendekatan keterampilan proses sains dalam belajar mengajar bertujuan:

(1) untuk memberikan motivasi belajar kepada siswa karena dalam keterampilan proses siswa senantiasa berpartisipasi secara aktif dalam belajar;

(2) untuk memperdalam konsep, pengertian, dan fakta yang dipelajari siswa karena pada hakikatnya siswa sendirilah yang mencari dan menemukan konsep tersebut;

(3) untuk menerapkan teori dalam kehidupan masyarakat;

(4) sebagai persiapan dan latihan dalam menghadapi kenyataan hidup di dalam masyarakat sebab siswa telah dilatih untuk berpikir logis dalam memecahkan masalah; dan

(5) untuk mengembangkan sikap percaya diri, bertanggung jawab, dan rasa kesetiakawanan sosial dalam menghadapi berbagai problem kehidupan.

Dalam pembelajaran fisika dengan keterampilan proses sains, seluruh irama gerak atau tindakan dalam proses belajar mengajar akan menciptakan kondisi belajar yang aktif. Menurut Dimyati dan Mudjiono (2006:139), mengajar dengan keterampilan proses berarti memberikan kesempatan kepada 
siswa bekerja dengan ilmu pengetahuan, tidak sekedar menceritakan atau mendengar cerita tentang ilmu pengetahuan. Oleh karena itu, guru bertindak sebagai fasilitator yang dapat menciptakan kondisi belajar siswa melalui pelaksanaan kegiatan pembelajaran yang syarat akan interaksi antara konsep/prinsip/teori yang telah ditemukan atau dikembangkan dengan pengembangan keterampilan proses sains.

Semiawan

(1992:14-15)

berpendapat bahwa terdapat empat alasan mengapa pendekatan keterampilan proses sains diterapkan dalam proses belajar mengajar seharihari, yaitu:

(1) Perkembangan ilmu pengetahuan berlangsung semakin cepat sehingga para guru tidak mungkin lagi mengajarkan semua fakta dan konsep kepada anak didiknya.

(2) Sesuai dengan pendapat para ahli psikologi yang mengatakan bahwa anak-anak mudah memahami konsep-konsep yang rumit dan abstrak jika diserta contoh-contoh konkret, contohcontoh yang wajar sesuai dengan situasi dan situasi yang dihadapi, dengan mempraktekan sendiri upaya penemuan konsep melalui perlakuan terhadap kenyataan fisik, melalui penanganan bendabenda yang benar nyata.

(3) Penemuan ilmu pengetahuan tidak bersifat mutlak benar seratus persen, penemuannya bersifat relatif.

(4) Dalam proses pembelajaran seharusnya pengembangan konsep tidak dilepaskan dari pengembangan sikap dan nilai dari anak didik.

Berdasarkan keempat alasan ini dicari cara mengajar-belajar yang sebaik- baiknya dengan melakukan pendekatan yang baru. Pendekatan itu adalah cara belajar siswa yang aktif yang mengembangkan keterampilan proses sains. Keterampilan proses sains ini melibatkan keterampilanketerampilan kognitif dan intelektual, manual dan sosial. Keterampilan proses sains atau intelektual yang terlibat dengan melekukan keterampilan proses peserta didik menggunakan pikirannya. Keterampilan manual jelas terlibat dalam keterampilan proses sains karena mungkin mereka melibatkan penggunaan alat dan bahan, pengukuran, penyusunan, atau perakitan alat. Dengan keterampilan proses sains dimaksudkan agar tercipta interaksi sesama anak didik dalam kegitan belajar mengajar dengan keterampilan proses sains.

Dari uraian tersebut, penelitian tindakan kelas ini berjudul "Upaya Meningkatkan Hasil Belajar IPA materi Pewarisan Sifat Melalui Model Cooperative Learning Tipe Student Team Achievement Division (STAD )Siswa Kelas 9H SMP Negeri Pakusari Jember tahun Pelajaran 2018/2019. Tujuan penelitian untuk mengetahui peningkatan hasil belajar siswa melalui model pembelajaran Student Team Achievement Division (STAD) pada materi Pewarisan Sifat kelas $9 \mathrm{H}$ di SMP Negeri Pakusari Jember tahun Pelajaran 2018/2019. 


\section{Jurnal Pembelajaran Fisika, Vol 9 No 2, Juni 2020, hal 86-94}

\section{METODE}

Penelitian ini dilaksanakan di kelas 9H di SMP Negeri Pakusari Jember. Sedangkan waktu penelitian dimulai dari bulan Agustus s/d Oktober 2018, dengan jumlah 35 orang siswa dengan jumlah siswa laki-laki 19 orang dan jumlah siswa perempuan 16 orang. Penelitian ini dilaksanakan sebanyak 2 siklus dengan 6 kali pertemuan. Prosedur tindakan yang dilakukan mengacu pada model yang dilakukan oleh Kemmis dan McTaggart dimana model tersebut menggambarkan adanya empat langkah (dan pengulangannya) dan keempat langkah tersebut merupakan satu siklus atau putaran yang terdiri atas (1) perencanaan, (2) pelaksanaan tindakan (3) pengamatan, dan (4) refleksi atau pantulan (Arikunto, 2006: hal 98-99)

Bentuk penelitian ini adalah Penelitian Tindakan Kelas. Peneliti merencanakan tindakan kelas dan merefleksi hasil tindakan. Pelaksanaan tindakan dilakukan oleh peneliti dan teman sejawat yang bertindak sebagai pengamat selama proses pembelajaran berlangsung. Sesuai dengan jenis penelitian tindakan kelas ini, maka desain penelitian tindakan kelas adalah strategi siklus dengan pelaksanaannya dengan dua siklus yaitu siklus I dan siklus II. Siklus I terdiri dari perencanaan tindakan, pelaksanaan tindakan, pengamatan dan refleksi. Hasil pengamatan dan refleksi pada siklus I diadakan perbaikan proses pembelajaran pada siklus II.

\section{HASIL DAN PEMBAHASAN}

Data hasil penelitian yang didapatkan pada siklus 1 sebesar = $89.47 \%$ Sebagaimana ditunjukkan pada Tabel 1

Tabel 1. Data Ketuntasan Hasil Belajar

\begin{tabular}{lcc}
\hline Presentasi tuntas belajar & $89.47 \%$ & $92.10 \%$ \\
\hline $\begin{array}{l}\text { Presentasi yang tidak tuntas } \\
\text { belajar }\end{array}$ & $10.52 \%$ & $7.89 \%$ \\
$\begin{array}{l}\text { Jumlah siswa yang tidak tuntas } \\
\text { belajar }\end{array}$ & 4 & 3 \\
\hline
\end{tabular}

Temuan penelitian yang diperoleh pada pelaksanaan penelitian ini adalah siswa merasa senang dengan belajar kelompok, karena dengan belajar kelompok mereka dapat saling bertukar pikiran/pendapat dengan teman. Pelaksanaan Cooperative Learning tipe STAD membuat siswa yang semula pasif menjadi aktif dalam kegiatan kelompok. Menurut siswa dengan belajar Cooperative Learning tipe STAD, siswa dapat saling bertanya jika mengalami kesulitan baik kepada guru maupun teman. Siswa lebih mudah memahami materi dengan adanya pengguaan metode belajar, yaitu Cooperative Learning tipe $S T A D$, dan juga siswa termotivasi dalam belajar untuk menjadi kelompok asal yang terbaik, mampu mentransfer pengalaman belajar pada pembelajaran sehingga mereka lebih mudah 
menemukan dan memahami kegiatan Cooperative Learning tipe STAD pada materi Pewarisan Sifat .

Penerapan Cooperative Learning tipe STAD pada materi Pewarisan Sifat di SMP Negeri Pakusari Jember terdiri dari 2 siklus. Setiap siklus terbagi menjadi 3 tahap, yaitu: 1) tahap awal, 2) tahap inti, dan 3) tahap akhir.
Berdasarkan keaktifan siswa dalam kegiatan yang telah dilakukan menun jukkan adanya peningkatan dari tiap tindakan. Perubahan positif pada keaktifan siswa berdampak pula pada prestasi belajar dan ketuntasan belajar. Hal ini dapat dilihat pada Tabel 2.

Tabel 2 Rata-rata hasil dan ketuntasan belajar siswa

\begin{tabular}{|l|c|c|c|}
\hline \multicolumn{1}{|c|}{ Kriteria } & Siklus I & Siklus II & Peningkatan \\
\hline Rata - rata hasil belajar siswa & 83.94 & 85 & 1.05 \\
\hline Ketuntasan belajar siswa & $89.47 \%$ & $92.10 \%$ & $2.63 \%$ \\
\hline
\end{tabular}

Dari Tabel 2 dapat diketahui bahwa ada peningkatan yang signifikan pada rata-rata hasil belajar siswa dari Siklus I ke siklus II, yaitu sebesar 1.05 begitu pula pada ketuntasan belajar matematika terjadi peningkatan sebesar $2.63 \%$ dari siklus I ke siklus II. Dengan demikian pada siklus II telah mencapai target awal bahwa Cooperative Learning tipe STAD mampu meningkatkan hasil prestasi belajar IPA. Hal ini sesuai dengan pendapat Edward, bahwa "Cooperative Learning tipe STAD telah unggul dalam meningkatkan hasil akademik bila dibandingkan dengan pengalaman belajar yang individu/kompetitif"'.

\section{Respon siswa terhadap Cooperative Learning tipe STAD}

Pada akhir siklus II diadakan wawancara terhadap tiga orang siswa yaitu siswa berkemampuan tinggi, berkemampuan sedang, dan siswa dengan kemampuan rendah. Berdasarkan hasil wawancara yang dilakukan oleh peneliti, menunjukkan bahwa Cooperative Learning tipe $S T A D$ yang telah diterapkan mendapat tanggapan yang positif dari siswa. Hal ini terbukti dari jawaban yang diberikan oleh ketiga siswa di atas, yang mengatakan bahwa dengan Cooperative Learning tipe STAD, siswa lebih berani untuk bertanya dan mengemukakan pendapatnya, siswa juga bisa memahami materi dengan cepat, bahkan semangat belajarnya semakin meningkat. Selain itu mereka dapat saling bertukar pikiran untuk memecahkan suatu permasalahan yang dihadapi secara besama-sama, saling bantu-membantu dan dilakukan tanpa membedakan jenis kelamin dan kemapuan siswa, sehingga mereka lebih mudah dalam memahami materi yang disampaikan. Selain dari wawancara, respon siswa terhadap pembelajaran ini, dapat diketahui dari hasil angket siswa. Berdasarkan hasil angket, diketahui bahwa siswa menunjukkan respon yang positif 
terhadap Cooperative Learning tipe STAD.

Hasil angket respon siswa sebagai berikut : siswa menjadi lebih aktif dalam belajar, baik dalam mengerjakan tugas-tugas yang diberikan maupun dalam berdiskusi, siswa senang dengan CooperativeLearning tipe STAD, siswa lebih cepat memahai materi dengan Cooperative Learning tipe STAD, dengan Cooperative Learning tipe STAD, siswa menjadi lebih bersemangat belajar IPA.

Lebih lanjut Wartono (2003:168) menuliskan bahwa pendekatan keterampilan proses sains merupakan pendekatan pembelajaran yang dalam penyususnan strategi mengajarnya mengembangkan keterampilanketerampilan proses sains bersamaan dengan fakta-fakta dan konsep-konsep serta prinsip sains dalam menyusun strategi mengajar.

\section{SIMPULAN DAN SARAN}

Berdasarkan hasil analisis dan pembahasan dapat dibuat kesimpulan sebagai berikut penerapan Cooperative Learning tipe STAD yang dapat meningkatkan hasil belajar siswa pada pokok bahasan Pewarisan Sifat . Hasil belajar siswa meningkat, dapat dilihat dari proses belajar mengajar dan nilai tes akhir. Untuk hasil observasi pada siklus I pengamatan aktivitas peneliti $79,28 \%$, aktivitas siswa 77,5 \% masuk dalam kategori baik, pada siklus II pengamatan aktivitas peneliti $90 \%$, aktivitas siswa 88\% masuk dalam kategori sangat baik. Begitu juga dengan hasil evaluasi untuk siklus
I yaitu 83.94 , untuk siklus II yaitu 85 , Dari hasil evaluasi tersebut dapat diketahui bahwa ada peningkatan yang signifikan pada rata-rata hasil belajar siswa dari Siklus I ke siklus II, yaitu sebesar 1.05. Hal ini menunjukkan bahwa pada siklus I ketuntasan belajar siswa belum tercapai yaitu sebesar 83.94, sedangkan pada siklus II meningkat menjadi 85 yang suadah memenuhikriteria ketuntasan minimum (KKM) 75 dan ketuntasan belajar siswa 85, pada siklus II menunjukkan peningkatan sebesar 1.05. Dengan demikian pada siklus II telah mencapai target, bahwa Coopetive Learning tipe STAD mampu meningkatkan hasil prestasi belajar IPA.

Siswa menunjukkan respon yang positif terhadap CooperativeLearning tipe STAD. Hal tersebut dapat diketahui dari hasil wawancara terhadap perwakilan siswa kelas $9 \mathrm{H}$, serta hasil angket respon siswa yang menunjukkan bahwa Cooperative Learning tipe STAD dapat meningkatkan semangat belajar siswa terhadap IPA.

\section{DAFTAR PUSTAKA}

Anas, Sudijono. 2008. Evaluasi Pendidikan. Jakarta: PT Raja GrafindoPersada.

Arifin, B, 2017. Penerapan Model Pembelajaran Kooperatif Tipe Student Team Achievement Division untuk Meningkatkan Prestasi Belajar IPS Pokok Bahasan Pendudukan Jepang di Indonesia Siswa Kelas V MIN 
Pucung Ngantru Tulungagung Tahun Ajaran 2016/2017. Tulungagung: Skripsi Tidak Diterbitkan.

Aprilia Fitriana, Nur Laili. 2013. Penerapan Model Pembelajaran Kooperatif Tipe Student Team Achievement Division (STAD) untuk Meningkatkan Minat Belajar PKN Materi Ciri Khas Bangsa Indonesia Kelas III MIN Pandansari Ngunut Tulungagung. : Skripsi Tidak Diterbitkan.

Conny, Semiawan. 2007. Belajar dan Pembelajaran Pra sekolah dan Sekolah Dasar , Jakarta: PT Macanan Jaya Cemerlang.

Dahar, 1995, Psikologi Pendidikan, Jakarta: Rineka Cipta.

Dimyati dan Mudjiono. 2006. Dikdaktik Metodik Dalam Mengajar dengan keterampilan proses. Jogjakarta: Think Jogjakarta.

I Gak,Wardani, et al. 2000. Penelitian Tindakan Kelas, Jakarta: Depdiknas.

Isjoni, 2010. Cooperative Learning Efektivitas Pembelajaran Kelompok. Bandung: Alfabeta.

Miles, M.B dan Huberman, 1992. Analisis data Kualitatif. Terjemahan oleh Tjejep Rohendi Rohidi. Jakarta: Universitas Indonesia Press.

Nurhadi. 2007. Pembelajaran Konstektual dan Penerapan dalam $K B K$, Malang; Universitas Negeri Malang.

Ngalim, Purwanto. 2006. Prinsip Prinsip dan Teknik Evalusi
Pengajaran. Jakarta: PT Remaja Rosdakarya.

Robet, S, E. 1995. Cooperative learning: theory reseach and practice. Boston: Allyn and balon.

Robert, Slavin, 2008, Cooperative Learning Teori, Riset, dan praktik. Terjemahan oleh Nurlita. Bandung: Nusa Media.

Suharsimi, A. 1992. Prosedur Penelitian Suatu pendekatan Praktek. Jakarta: Rineka Cipta.

Suharsimi, A. 2006. Prosedur Penelitian Suatu Pendekatan Praktik. Jakarta: PT Rineka Cipta

Suharsimi, A, dkk. 2006. Penelitian Tindakan Kelas, Jakarta: Bumi Aksara

Suharsimi, A. 2010. Dasar-Dasar Evaluasi Pendidikan. Jakarta: Bumi Aksara.

Usman, 1993, Mengapa harus Ketrampilan Proses. Surabaya: Prestasi Pustakaraya.

Wartono. 2003. Ketrampilan Proses Sains, Yogyakarta: Bumi Aksara

Yatim, R. 2001. Metodologi Penelitian Pendidikan. Surabaya: Anggota IKAPI. 